\title{
Aluminum extraction from coal ash by a two-step acid leaching method*
}

\author{
Pei-wang ZHU, Hua DAI, Lei HAN, Xiu-lin XU, Le-ming CHENG, Qin-hui WANG, Zheng-lun SHI ${ }^{\dagger \neq}$ \\ (State Key Laboratory of Clean Energy Utilization, Zhejiang University, Hangzhou 310027, China) \\ ${ }^{\dagger} E$-mail: szl@zju.edu.cn
}

Received July 4, 2014; Revision accepted Oct. 13, 2014; Crosschecked Jan. 23, 2015

\begin{abstract}
To improve aluminum extraction efficiency, a two-step acid leaching process was proposed to dissolve aluminum and aluminum-bearing crystals with sulfuric acid. The first leaching residue (FLR) was obtained through direct leaching of coal ash with sulfuric acid. After roasting a mixture of the FLR and sodium carbonate, the aluminum-bearing crystals in FLR were completely destroyed while sodium silicate was generated. Then the roasted products were leached with water to dissolve the sodium carbonate. X-ray diffraction (XRD) analysis indicated that the water leaching residues (WLR) mainly contained the amorphous phase, which allowed easy aluminum extraction in the second leaching step. In the first leaching test with $10 \mathrm{~mol} / \mathrm{L}$ sulfuric acid at $120{ }^{\circ} \mathrm{C}$ in $2 \mathrm{~h}$ and a solid to liquid ratio $(\mathrm{S} / \mathrm{L})$ of $1: 2$, aluminum dissolution from raw coal ash reached $81.72 \%$. In the second leaching step with $5 \mathrm{~mol} / \mathrm{L}$ sulfuric acid, the aluminum dissolutions from WLR were $87.31 \%$ at $20{ }^{\circ} \mathrm{C}$ and $99.06 \%$ at $100{ }^{\circ} \mathrm{C}$. Total aluminum dissolutions were more than $97 \%$. Moreover, the leaching process produced two by-products, sodium silicate solution and amorphous silicon dioxide, which contained nearly all the silicon from the coal ash.
\end{abstract}

Key words: Coal ash, Aluminum dissolution, Acid leaching, Roasting doi: $10.1631 /$ jzus.A1400195

\section{Introduction}

Bauxite reserves in China are estimated at 3.2 billion tons, which will be consumed in 20 years (Liu et al., 2009). But alumina reserves in domestic coal have been more than 31.9 billion tons since 2008 (Dai et al., 2012). Moreover, the huge consumption of coal in China produces a large amount of coal ash. In coal fly ash of Classes $\mathrm{F}$ and $\mathrm{N}$ as specified by the American Society for Testing and Materials (ASTM C618-00:2001), $\mathrm{SiO}_{2}, \mathrm{Al}_{2} \mathrm{O}_{3}$, and $\mathrm{Fe}_{2} \mathrm{O}_{3}$ account for more than $70 \%$ in weight. Roughly landfilling or heaping coal ash not only pollutes the environment

\footnotetext{
ॠCorresponding author

* Project supported by the National High-Tech R\&D Program (863 Program) of China (No. 2013AA051203)

(ib) ORCID: Pei-wang ZHU, http://orcid.org/0000-0002-9892-0141; Zheng-lun SHI, http://orcid.org/0000-0002-3344-2943

(C) Zhejiang University and Springer-Verlag Berlin Heidelberg 2015
}

(Xue and $\mathrm{Lu}, 2008$ ), but also wastes resources. Consequently, utilization of coal ash resources has been an urgent research task (Cao et al., 2008). However, different elements in coal ash can generate new crystals when coal ash is fired at high temperatures (Quispe et al., 2012), thus increasing the difficulty of recovering valuable elements. In a pulverized coal boiler, aluminum and silicon in coal ash can be converted into mullite when the temperature is above $1000{ }^{\circ} \mathrm{C}$. In a circulating fluidized bed boiler, feldspar and mica crystals in coal cannot be completely destroyed at low temperatures, and coal ash produced under the above conditions contains only a small quantity of amorphous Al-Si material. Thus, the coal ash lacks activity, which is unfavorable for extracting aluminum and silicon.

As the aluminum-containing crystals restrict the aluminum extraction efficiency of the acid method (Wang et al., 2014), many researchers have studied alkali methods. However, the traditional Bayer 
process is unsuitable for dissolving alumina from ash as silica dissolves in alkaline solutions to an unacceptable degree (Jackson, 1986). Matjie et al. (2005) and Li et al. (2009) proposed alkali fusion methods, in which basic salts like calcium carbonate and sodium carbonate are used to recover alumina. However, these methods need high temperature calcination and generate a large amount of waste, making the process energy intensive, uneconomical, and environmentally unfriendly (Nayak and Panda, 2010; Du et al., 2011; Yang et al., 2012).

Although the acid leaching method has low aluminum extraction efficiency, it avoids high energy consumption and large waste residues. Many researchers have therefore focused on improving this method. Harada et al. (1993) reported a method of decomposing mullite by mixing $0.5 \mathrm{~g}$ of powdered mullite sample with $5 \mathrm{ml}$ of concentrated sulfuric acid in a polytetra-fluoroethylene pressured vessel and heating at $230{ }^{\circ} \mathrm{C}$ for $16 \mathrm{~h}$. Huang et al. (1999) reported that $90 \%$ of alumina was leached with sulfuric acid when fluoride was used as additive at 125$135{ }^{\circ} \mathrm{C}$ for $2-2.5 \mathrm{~h}$. Although hydrofluoric acid was effective in decomposing the mullite in coal ash, it was an environmental hazard (Bai et al., 2010).

To improve the leaching efficiency, a two-step leaching process is proposed for aluminum extraction with sulfuric acid. First, coal ash is directly leached. Residues with undissolved aluminum are mixed with sodium carbonate and roasted at a certain temperature After leaching the roasted product with water, most sodium silicate is removed and aluminum remains in the water leaching residues (WLR). Second, sulfuric acid is used to leach the rest of the aluminum in the WLR. This work is focused on the conditions of the two-step leaching process to get the highest total aluminum extraction efficiency.

\section{Experimental}

\subsection{Raw materials}

Coal ash was obtained from a circulating fluidized bed boiler power plant in northeast China. Low heating value coal gangue was the feed for combustion in the range of $800{ }^{\circ} \mathrm{C}$ to $900{ }^{\circ} \mathrm{C}$. The coal ash samples were crushed and dried for analysis of particle size, chemical composition, and mineralogical composition. Measurements by the Malvern Mastersizer 2000 indicated particle size distribution $d_{90} \leq$ $0.74 \mu \mathrm{m}$. Table 1 shows the chemical composition of the coal ash. It contains $27.34 \%$ of $\mathrm{Al}_{2} \mathrm{O}_{3}$ in weight, which is close to the average alumina content $(27.8 \%)$ in Chinese coal ash (Shao et al., 2007). Thus, this coal ash sample is a representative sample for China.

Table 1 Chemical composition of the coal ash

\begin{tabular}{cc||cc}
\hline Component & Mass (\%) & Component & Mass (\%) \\
\hline $\mathrm{K}_{2} \mathrm{O}$ & 1.28 & $\mathrm{Al}_{2} \mathrm{O}_{3}$ & 27.34 \\
$\mathrm{Na}_{2} \mathrm{O}$ & 0.58 & $\mathrm{Fe}_{2} \mathrm{O}_{3}$ & 6.71 \\
$\mathrm{TiO}_{2}$ & 0.83 & $\mathrm{CaO}$ & 0.23 \\
$\mathrm{SiO}_{2}$ & 60.38 & $\mathrm{MgO}$ & 1.59 \\
\hline $\mathrm{LOI}^{*}$ & 1.02 & \multicolumn{2}{l}{} \\
\hline
\end{tabular}

${ }^{*}$ Loss on ignition, calcining at a temperature of $900{ }^{\circ} \mathrm{C}$

\subsection{Analytical methods}

The chemical composition of the coal ash was estimated by an energy dispersive X-ray fluorescence (ED-XRF) analyzer (Spectro Analytical Instruments $\mathrm{GmbH}$, Germany). The measurement program covered the elements from sodium to germanium with a measurement time of $15 \mathrm{~min}$ per iteration. The ethylene diamine tetraacetic acid (EDTA) titration method (ChPC, 2000) was used for the elemental analysis of aluminum and iron ions generated during the acid leaching process.

$\mathrm{X}$-ray diffraction (XRD) analysis was performed by a D/Max-2550pc powder diffractometer (Rigaku, Japan), using $\mathrm{Cu} \mathrm{K}_{\alpha}(\lambda=0.154059 \mathrm{~nm})$ radiation at $40 \mathrm{kV}$ and $250 \mathrm{~mA}$. The scans were run from $5^{\circ}$ to $85.0^{\circ}(2 \theta)$, with an increasing step size of $0.02^{\circ}$ and a scan rate of $5 \% \mathrm{~min}$. Data were processed by using MDI-Jade version 7.0 software.

The morphologies of samples, adhered on paper and metallized with gold in advance, were observed by scanning electron microscope (SEM) (Quanta 3D FEG, FEI, USA) with a magnification from 20000 to 50000 .

\subsection{Experimental process}

The detailed two-step acid leaching process is shown in Fig. 1. First, coal ash was directly leached with sulfuric acid. After filtration, the first leachate and the first leaching residues (FLR) were obtained. Then the first aluminum leaching rate $\eta_{1}(\%)$ could be calculated. Second, the FLR were mixed evenly with 
sodium carbonate and roasted at $860{ }^{\circ} \mathrm{C}$ for $2 \mathrm{~h}$ in a muffle furnace. The amount of sodium carbonate added depended on the amount of $\mathrm{SiO}_{2}$ that existed in the FLR, to give a 1:1 molar ratio of $\mathrm{Na}_{2} \mathrm{CO}_{3}$ to $\mathrm{SiO}_{2}$. The actual amount of $\mathrm{Na}_{2} \mathrm{CO}_{3}$ was in excess of $5 \%$. Third, after leaching the roasted product with water, most of the sodium silicate was dissolved and aluminum remained in the WLR. Finally, sulfuric acid was used to leach the rest of the aluminum in the WLR. Through filtration, the second leachate and the second leaching residues (SLR) were obtained. The second aluminum leaching rate was set as $\eta_{2}(\%)$. Then the overall aluminum extraction efficiency $\eta(\%)$ could be calculated as

$$
\eta=\eta_{1}+\left(100-\eta_{1}\right) \eta_{2} / 100
$$

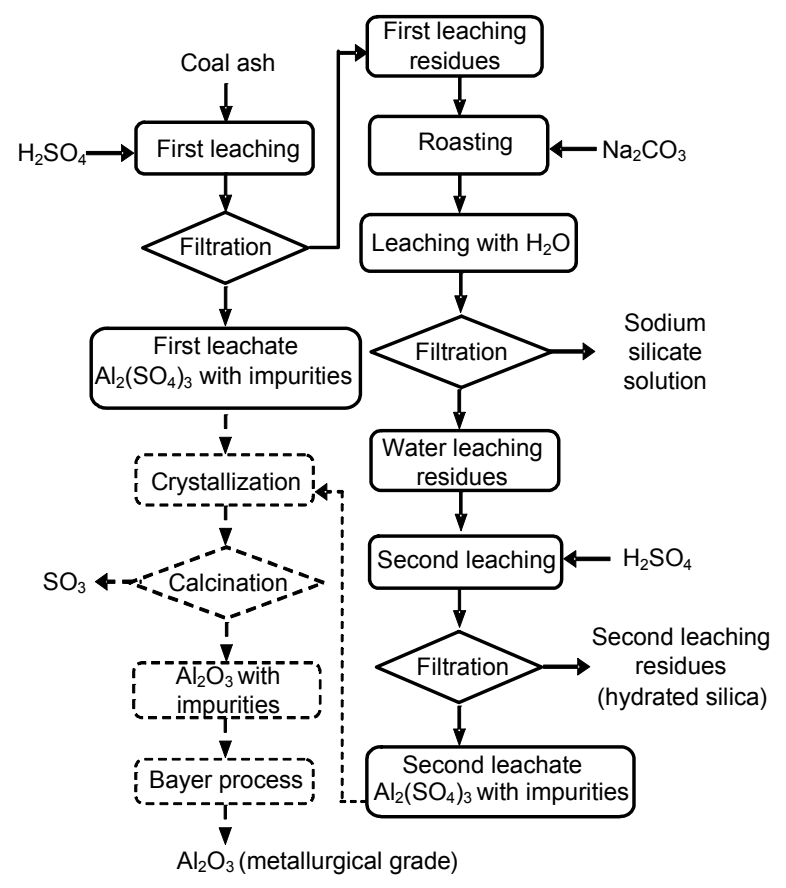

Fig. 1 Process flowchart of aluminum extraction with the two-step acid leaching method

Acid leaching tests were conducted to study the effects of acid concentration, reaction temperature, leaching time, and solid to liquid ratio $(\mathrm{S} / \mathrm{L})$ on the aluminum leaching rate. The desired concentrations of sulfuric acid were prepared by dissolving known volumes of acids with distilled water. Erlenmeyer flasks containing the leaching agent were placed in a magnetic oil bath for heating under a constant stirring condition. After heating the leaching agent to a preset temperature, $50 \mathrm{mg}$ coal ash and a magnetic stirring bar were added to the leaching agent. Leaching time was counted from agitation. Finally, the leaching residues were separated from the leaching liquor by filtration and were washed more than three times with hot deionized water. The whole liquor was collected and diluted to $1000 \mathrm{ml}$ in a volumetric flask with deionized water. The diluted liquor was analyzed to give the concentrations of aluminum and iron ions.

\section{Results and discussion}

\subsection{First leaching of coal ash with $\mathrm{H}_{2} \mathrm{SO}_{4}$}

Fig. 2a shows the aluminum dissolution under various concentrations of sulfuric acid at different leaching times. The mixture was heated to boiling point within the range of $105^{\circ} \mathrm{C}$ to $170{ }^{\circ} \mathrm{C}$, depending on the acid concentration. To maintain the desired $\mathrm{S} / \mathrm{L}$ of $1: 2 \mathrm{~g} / \mathrm{ml}$, an appropriate amount of warm deionized water was added from time to time. Results showed that under different leaching time conditions, the aluminum dissolution variation with acid concentration had similar characteristics. With the increase of acid concentration, the aluminum dissolution initially increased and then decreased. For example, under $0.5 \mathrm{~h}$ leaching condition, the aluminum dissolution increased from $60 \%$ to $76.44 \%$ and then fell to $73.58 \%$; under $6 \mathrm{~h}$ leaching condition, the aluminum dissolution increased from $73.44 \%$ to $83.51 \%$ and then fell to $79.57 \%$. Under different leaching times, the maximum aluminum dissolution was always obtained at a sulfuric acid concentration of $10 \mathrm{~mol} / \mathrm{L}$. When the sulfuric acid concentration was increased from $10 \mathrm{~mol} / \mathrm{L}$ to $12 \mathrm{~mol} / \mathrm{L}$, the aluminum dissolution decreased due to the availability of less water in the more concentrated acid for mass transfer during the leaching reaction. Thus, the optimum sulfuric acid concentration for aluminum dissolution is $10 \mathrm{~mol} / \mathrm{L}$.

The leaching time also has a significant impact on aluminum dissolution. As shown in Fig. 2b, at a sulfuric acid concentration of $10 \mathrm{~mol} / \mathrm{L}$, aluminum dissolution is sharply increased with the increase of leaching time from 0.5 to $2 \mathrm{~h}$. After $2 \mathrm{~h}$ leaching, aluminum dissolution reaches $81.72 \%$. After $4 \mathrm{~h}$ and $6 \mathrm{~h}$ leaching, the aluminum dissolution was $82.97 \%$ and $83.51 \%$, respectively. It can be concluded that 
doubling leaching time beyond $2 \mathrm{~h}$ only results in a small improvement in aluminum dissolution, and is uneconomical.

The effect of reaction temperature on aluminum dissolution was studied at two levels of time (Fig. 3a). Similar trends of aluminum dissolution variation with temperature were obtained under different leaching time conditions, demonstrating that the aluminum dissolution increased with the increase of temperature. But above $120{ }^{\circ} \mathrm{C}$, aluminum dissolution only increased a little. Fig. $3 a$ also shows that with the increase of reaction temperature, the differences in aluminum dissolution became smaller under different leaching times. At $100{ }^{\circ} \mathrm{C}$, the aluminum dissolution in $2 \mathrm{~h}$ and $4 \mathrm{~h}$ was $63.66 \%$ and $72.19 \%$, respectively. At $140{ }^{\circ} \mathrm{C}$, the aluminum dissolution in $2 \mathrm{~h}$ and $4 \mathrm{~h}$ was $85.80 \%$ and $86.16 \%$, respectively. These indicate that the changes at low temperatures (below $120{ }^{\circ} \mathrm{C}$ ) had a significant impact on the leaching efficiency and reaction rate but that changes at high temperatures (over $120^{\circ} \mathrm{C}$ ) had a weak impact.

Aluminum dissolution showed little change with varying $\mathrm{S} / \mathrm{L}$ and constant concentration of $10 \mathrm{~mol} / \mathrm{L}$ sulfuric acid at $120^{\circ} \mathrm{C}$ in $2 \mathrm{~h}$ (Fig. 3b). From 1:2 to 1:5 for $\mathrm{S} / \mathrm{L}$, all the aluminum dissolutions were around $85 \%$. Thus, an $\mathrm{S} / \mathrm{L}$ of $1: 2$ economizes sulfuric acid. The leaching rate is high and the process is practically unhindered, in spite of the quick formation of an inwardly expanding ash layer, resulting from the leaching of material from the coal ash particle (Seidel and Zimmels, 1998).

\subsection{Mineralogical analysis}

Fig. 4a shows the XRD pattern of pre-leached coal ash. Both crystal and non-crystal materials can be found through their characteristic diffraction
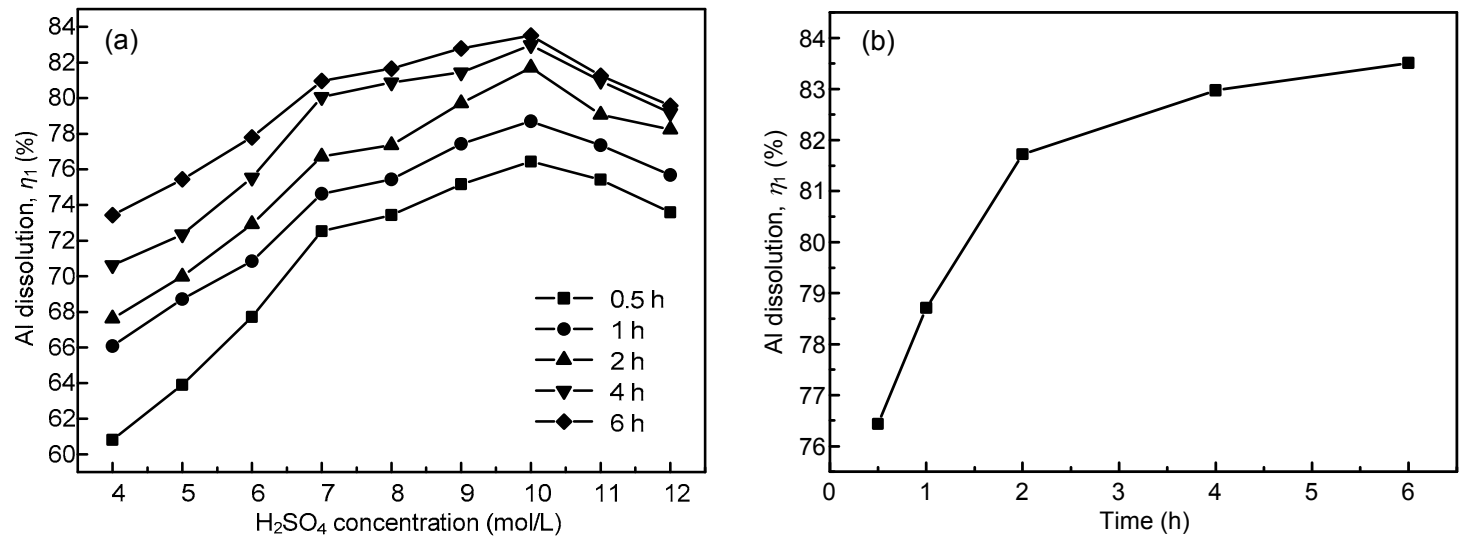

Fig. 2 Effects of sulfuric acid on aluminum dissolutions from coal ash $\left(\eta_{1}\right)$ at each boiling point with an S/L of 1:2 (a) Effect of acid concentration; (b) Effect of leaching time at $10 \mathrm{~mol} / \mathrm{L}$ acid concentration
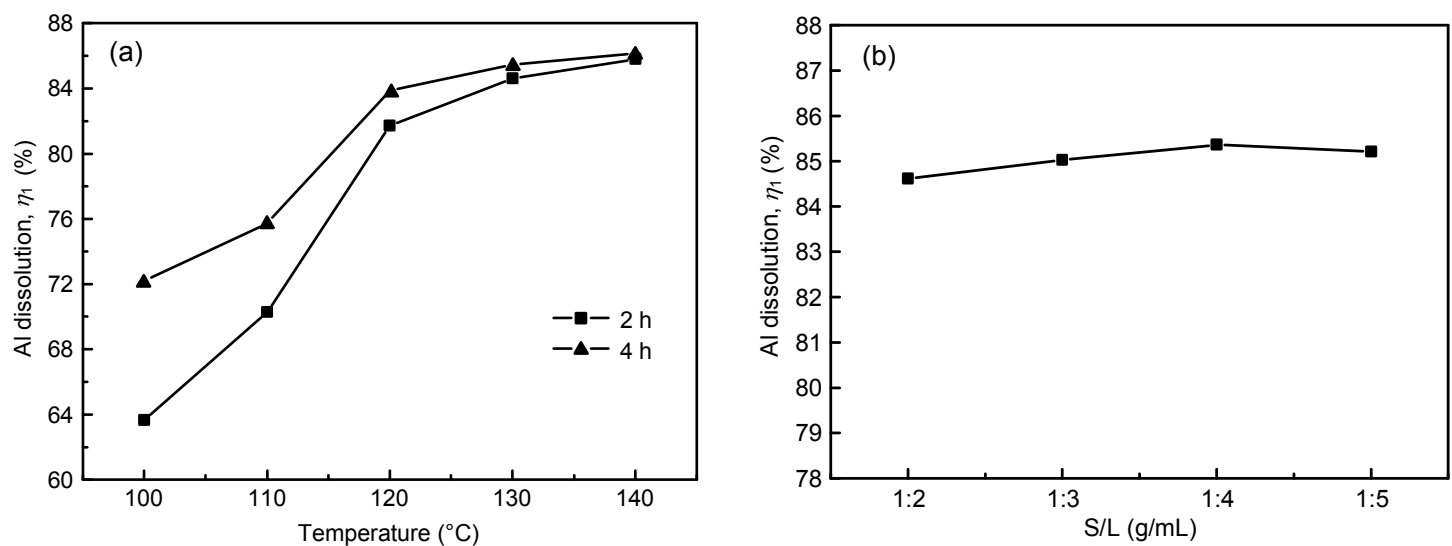

Fig. 3 Effects of sulfuric acid on aluminum dissolution from coal ash $\left(\eta_{1}\right)$ at $10 \mathrm{~mol} / \mathrm{L}$ acid concentration (a) Effect of temperature with an S/L of 1:2; (b) Effect of $\mathrm{S} / \mathrm{L}$ at $120^{\circ} \mathrm{C}$ in $2 \mathrm{~h}$ 
profiles. The reflection of quartz is the major mineral phase. Other reflections, such as microcline and hematite, are minor phases. The non-crystal materials are estimated to be aluminum-bearing materials as the raw coal ash contains $27.34 \% \mathrm{Al}_{2} \mathrm{O}_{3}$ in weight (Table 1), which is the second major oxide in coal ash. Fig. $4 \mathrm{~b}$ shows the XRD pattern of post-leached coal ash with $10 \mathrm{~mol} / \mathrm{L}$ sulfuric acid at $120^{\circ} \mathrm{C}$ in $2 \mathrm{~h}$. It shows that quartz and microcline remain in the FLR, but hematite has disappeared. Chemical analysis showed that iron dissolution was $90.61 \%$ under that condition. Thus, it can be inferred that nearly all of the iron in the hematite was dissolved by sulfuric acid, but none or only a little aluminum in the microcline was dissolved. More than $80 \%$ aluminum leached in the first leaching stage suggests the leached aluminum was from non-crystalline materials. The elemental analysis of FLR supports the above conclusions. The FLR, obtained under the condition of $10 \mathrm{~mol} / \mathrm{L}$ sulfuric acid at $120^{\circ} \mathrm{C}$ in $2 \mathrm{~h}$, contained $1.2 \% \mathrm{~K}_{2} \mathrm{O}$ in weight (Table 2). It is close to the $1.28 \%$ of $\mathrm{K}_{2} \mathrm{O}$ in raw coal ash.

The key problem in improving the efficiency of aluminum extraction is how to decompose the microcline completely and leach the aluminum in it. As mentioned above, sodium carbonate was used as an additive for the roasting of the FLR. The fusion of sodium carbonate occurs at $851{ }^{\circ} \mathrm{C}$. Therefore, the possible chemical reactions involved in this roasting step at $860^{\circ} \mathrm{C}$ are as follows:

$$
\begin{gathered}
\mathrm{SiO}_{2}+\mathrm{Na}_{2} \mathrm{CO}_{3}=\mathrm{Na}_{2} \mathrm{SiO}_{3}+\mathrm{CO}_{2} \uparrow, \\
\mathrm{Al}_{2} \mathrm{O}_{3}+2 \mathrm{SiO}_{2}+\mathrm{Na}_{2} \mathrm{CO}_{3}=2 \mathrm{NaAlSiO}_{4}+\mathrm{CO}_{2} \uparrow, \\
\mathrm{KAlSi}_{3} \mathrm{O}_{8}+2 \mathrm{Na}_{2} \mathrm{CO}_{3}=\mathrm{KAlSiO}_{4}+2 \mathrm{Na}_{2} \mathrm{SiO}_{3}+2 \mathrm{CO}_{2} \uparrow .
\end{gathered}
$$

The FLR used in this process was obtained under the condition of $10 \mathrm{~mol} / \mathrm{L}$ sulfuric acid at $120{ }^{\circ} \mathrm{C}$ in $2 \mathrm{~h}$. After roasting and water leaching, the roasted product and WLR were tested by XRD. The results are presented in Fig. 5. It was found that quartz and microcline were completely decomposed while sodium silicate and a few amorphous materials were generated (Fig. 5a). Fig. 5b indicates that the sodium silicate in the WLR was dissolved and that the residues were some amorphous materials and a little cordierite. The WLR kept all the aluminum that remained in the FLR. Since sulfuric acid can dissolve the amorphous materials and cordierite, the second leaching with the WLR can be worked out.
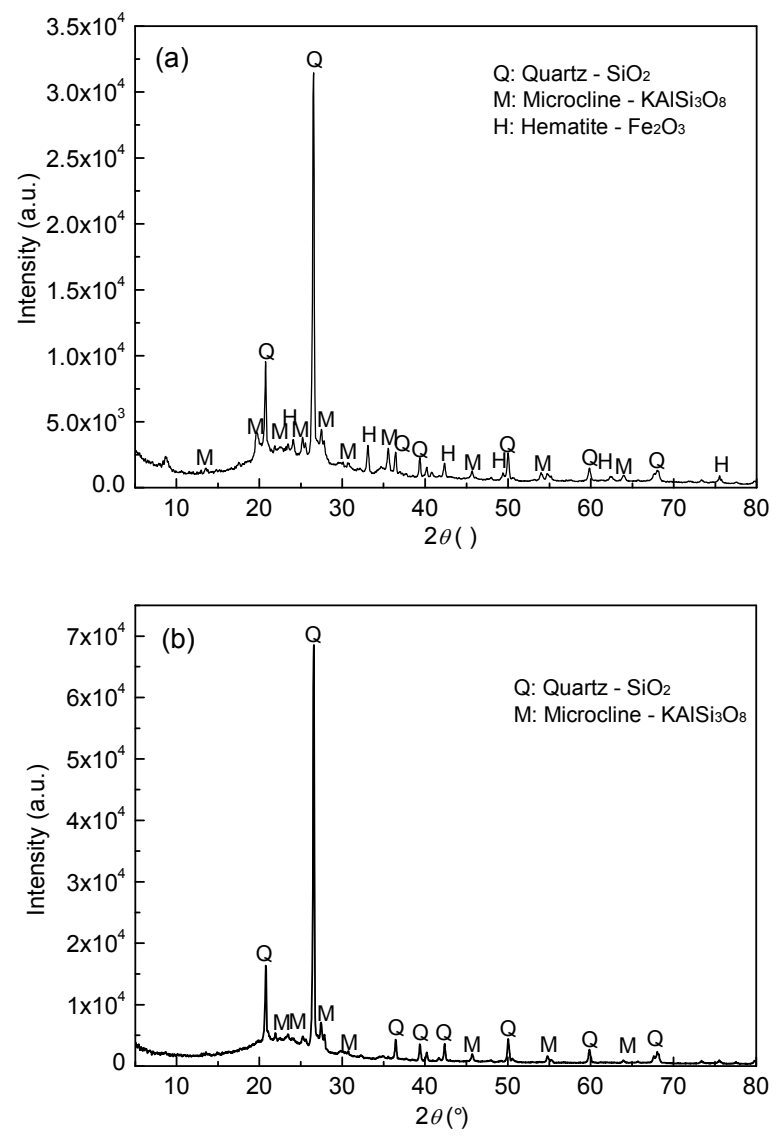

Fig. 4 XRD patterns

(a) Raw coal ash; (b) FLR from coal ash with $10 \mathrm{~mol} / \mathrm{L}$ sulfuric acid at $120^{\circ} \mathrm{C}$ in $2 \mathrm{~h}$ and an $\mathrm{S} / \mathrm{L}$ of $1: 2$

Table 2 Chemical composition of the first leaching residue (FLR)

\begin{tabular}{cc||cc}
\hline Component & Mass (\%) & Component & Mass (\%) \\
\hline $\mathrm{K}_{2} \mathrm{O}$ & 1.20 & $\mathrm{Al}_{2} \mathrm{O}_{3}$ & 8.33 \\
$\mathrm{Na}_{2} \mathrm{O}$ & 0.44 & $\mathrm{Fe}_{2} \mathrm{O}_{3}$ & 0.67 \\
$\mathrm{TiO}_{2}$ & 0.19 & $\mathrm{CaO}$ & - \\
$\mathrm{SiO}_{2}$ & 84.62 & $\mathrm{MgO}$ & 0.76 \\
\hline $\mathrm{LOI}^{*}$ & 3.73 & & \\
\hline
\end{tabular}

" Calcining at a temperature of $900{ }^{\circ} \mathrm{C}$

\subsection{Morphological analysis by SEM}

In Fig. 6a, the original coal ash particle was covered by some flakes which were thinner than $1 \mu \mathrm{m}$. Under these flakes, the surfaces of coal ash particles appeared to be smooth and flat, indicating amorphous materials. They were dense due to calcination. After leaching with sulfuric acid, the smooth surfaces of the particles were destroyed (Fig. 6b), but the flakes remained. These flakes, which covered the particles or 

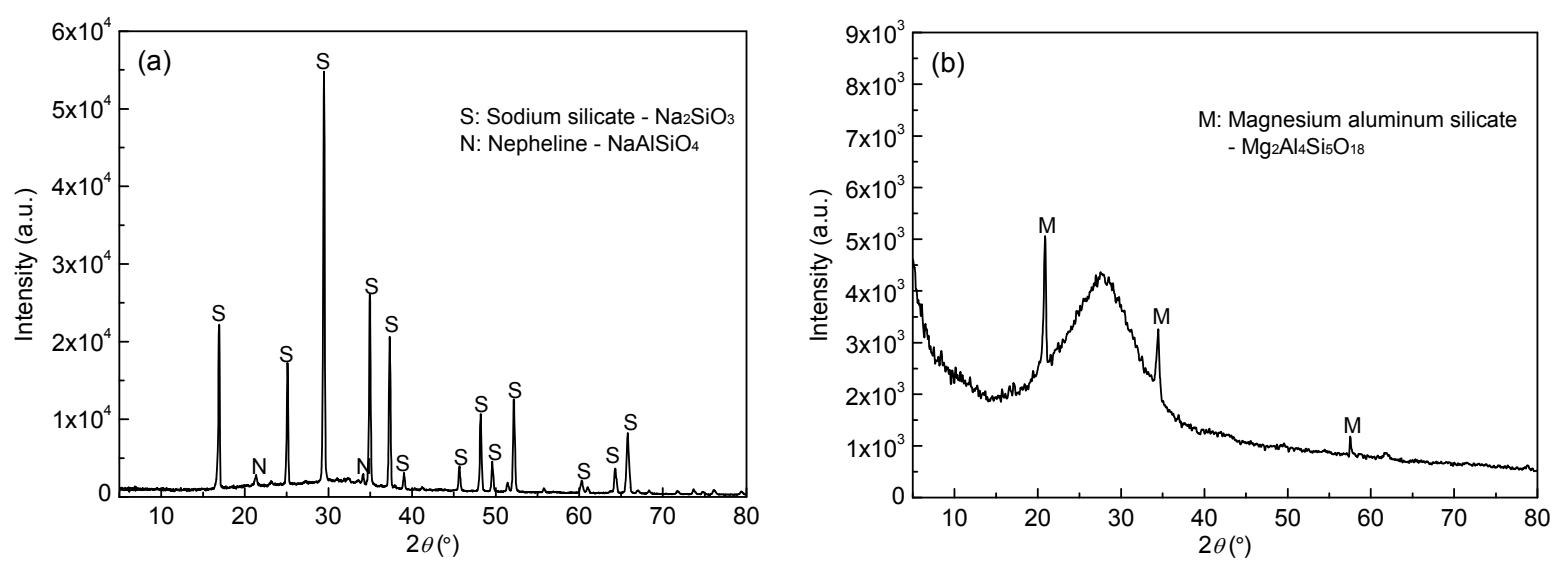

Fig. 5 XRD patterns of the roasted product (a) and WLR (b)

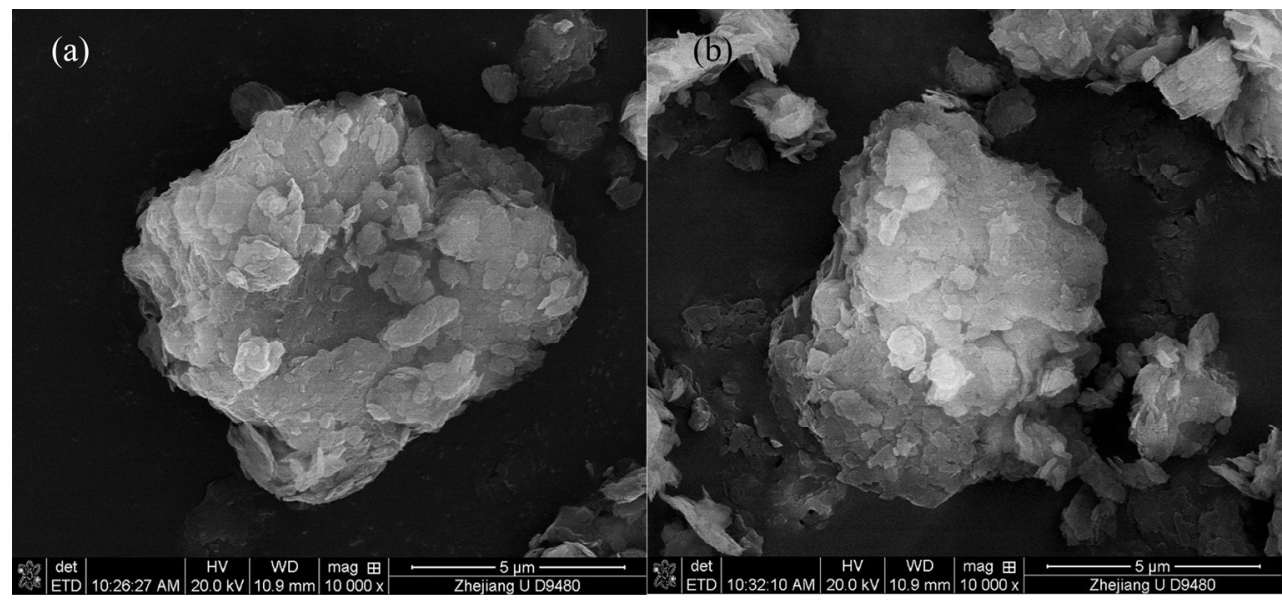

Fig. 6 SEM images of original coal ash (a) and FLR (b) from coal ash with $10 \mathrm{~mol} / \mathrm{L}$ sulfuric acid at $120^{\circ} \mathrm{C}$ in $2 \mathrm{~h}$ and an S/L of 1:2

appeared as individual particulates, were more dispersed. It indicated that sulfuric acid removed the aluminum in the amorphous phase but the crystalline phase remained in the flakes. The results were consistent with the study of XRD. Fig. 6 also shows that during the leaching test, the particle size changed little. This behavior, which was also reported by Berry et al. (1986), was the characteristic of shrinking core model reactions.

After roasting the mixture of FLR and sodium carbonate, the roasted products were observed by SEM. As shown in Fig. 7a, the morphological characteristics presented significant differences. The previous flakes and vitreous body had disappeared and been replaced by a fusion-like complex. Many tiny bulges were observed on the fusion-like complex. It was assumed that these were generated because the flakes were broken after partial fusion and then they were shrunk due to surface tension. This suggested that thermal chemical treatment completely destroyed the morphological appearance of the FLR.

Fig. $7 \mathrm{~b}$ is the SEM image of the WLR. It showed that the WLR was a loose and porous floccule which was aggregated with small particles. This suggested that water leaching dissolved most of the fusion-like complex. It appeared that the WLR was characterized by low density, high porosity, high specific surface area, and high chemical reactivity.

\subsection{Second leaching of the WLR with $\mathrm{H}_{2} \mathrm{SO}_{4}$}

During the water leaching process, $86.82 \%$ of $\mathrm{SiO}_{2}$ in the FLR was dissolved. The rest of the silicon and aluminum remained in the WLR. The chemical composition of the WLR was as follows (in weight): 
$\mathrm{SiO}_{2}(51.06 \%), \mathrm{Al}_{2} \mathrm{O}_{3}(18.94 \%), \mathrm{Fe}_{2} \mathrm{O}_{3}(1.24 \%), \mathrm{CaO}$ $(0.20 \%), \mathrm{MgO}(1.13 \%), \mathrm{Na}_{2} \mathrm{O}(12.87 \%), \mathrm{K}_{2} \mathrm{O}(1.04 \%)$, and LOI (14.69\%). Fig. 8 shows the second leaching results with $5 \mathrm{~mol} / \mathrm{L}$ sulfuric acid in $2 \mathrm{~h}$ and an $\mathrm{S} / \mathrm{L}$ of $1: 3$.

From $40{ }^{\circ} \mathrm{C}$ to $80{ }^{\circ} \mathrm{C}$, aluminum dissolution improved rapidly with increase in temperature. At $100{ }^{\circ} \mathrm{C}$, aluminum dissolution from the WLR reached $99.06 \%$. At $20^{\circ} \mathrm{C}$, aluminum dissolution was $87.31 \%$. The high aluminum dissolution could be explained in three ways. First, amorphous material was the main component in the WLR. Second, loose and porous WLR resulted in a huge effective contact area with sulfuric acid. Third, aluminum-bearing cordierite could be dissolved by sulfuric acid at $20^{\circ} \mathrm{C}$, which was demonstrated by the XRD pattern of the SLR (Fig. 9a). Fig. 9b shows the SEM image of SLR. Chemical detection indicated that the SLR was dominated by $\mathrm{SiO}_{2}$.
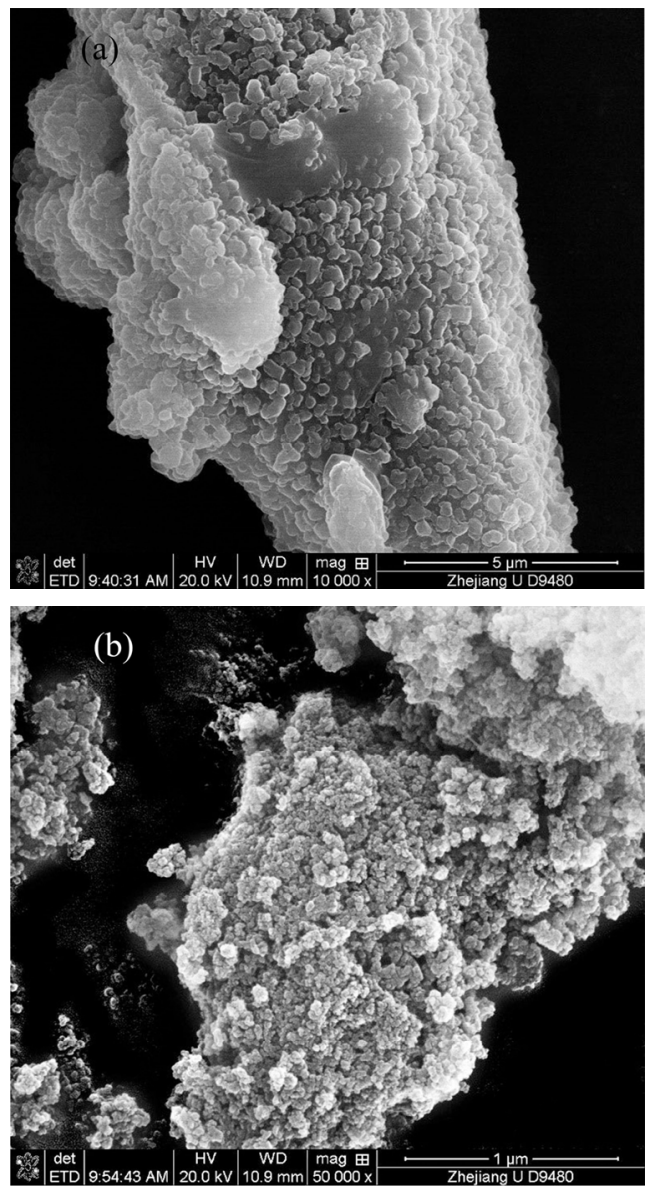

Fig. 7 SEM images of the roasted product (a) and WLR (b)
In the first leaching test with $10 \mathrm{~mol} / \mathrm{L}$ sulfuric acid at $120{ }^{\circ} \mathrm{C}$ in $2 \mathrm{~h}$ and an $\mathrm{S} / \mathrm{L}$ of $1: 2$, aluminum dissolution $\eta_{1}$ from raw coal ash reached $81.72 \%$. Aluminum dissolution $\eta_{2}$ from the WLR in the second

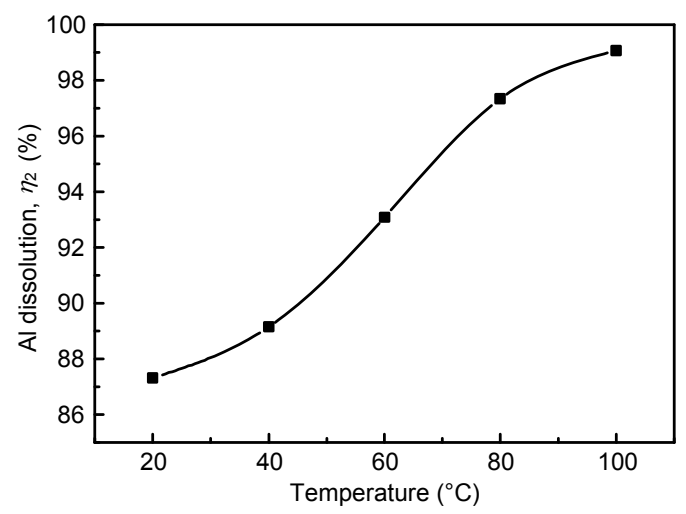

Fig. 8 Aluminum dissolution from WLR $\left(\eta_{2}\right)$ varying with temperature at $5 \mathrm{~mol} / \mathrm{L}$ acid concentration in $2 \mathrm{~h}$ and an $S / L$ of $1: 3$
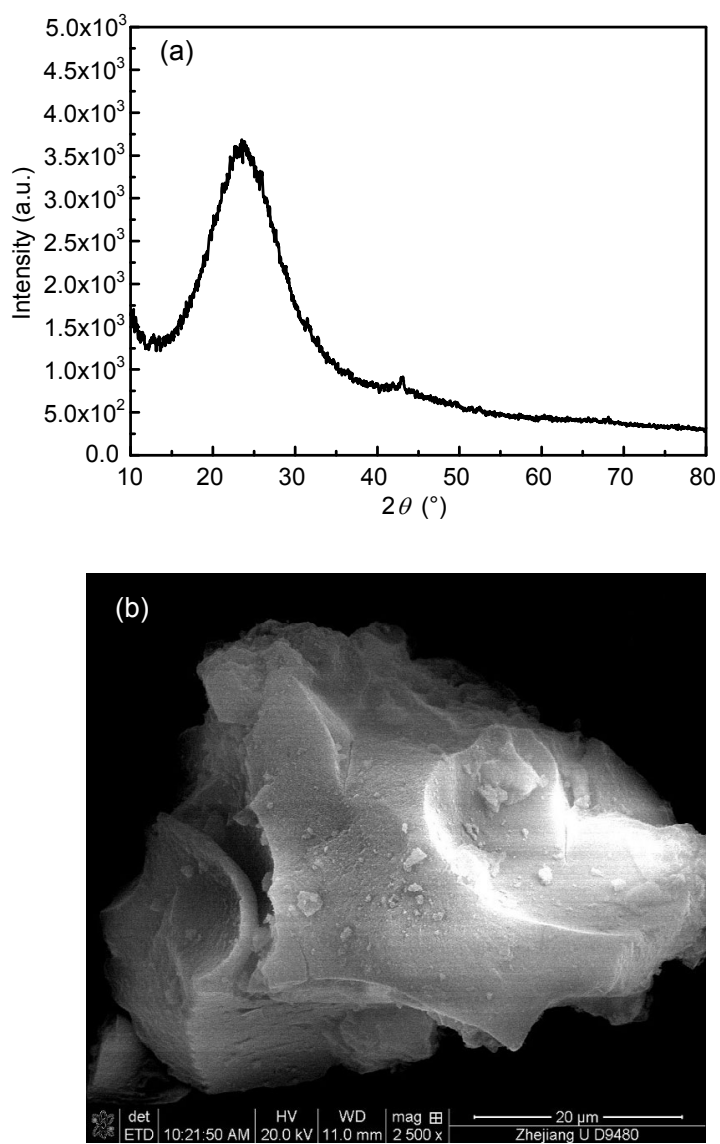

Fig. 9 Characteristics of SLR: (a) XRD pattern; (b) SEM image 
leaching tests varied with temperature. Total aluminum dissolutions were calculated by Eq. (1), which are $97.68 \%, 98.02 \%, 98.74 \%, 99.51 \%$, and $99.83 \%$ at the temperatures of the second leaching of 20, 40, 60, 80 , and $100{ }^{\circ} \mathrm{C}$, respectively. Through the two-step leaching process, high aluminum dissolutions (97.68\%-99.83\%) were obtained. The results suggested that aluminum and silicon in coal ash were separated effectively.

\section{Conclusions}

Through a two-step leaching process, amorphous and crystal phases of aluminum in coal ash were leached under atmospheric pressure. For effective separation impurities other than $\mathrm{Al}^{3+}$ need to be removed through a suitable process. The dashed part in Fig. 1 shows one kind of alumina recovery for metallurgy. The following conclusions can be drawn:

1. In the first leaching test with $10 \mathrm{~mol} / \mathrm{L}$ sulfuric acid at $120^{\circ} \mathrm{C}$ in $2 \mathrm{~h}$ and an $\mathrm{S} / \mathrm{L}$ of $1: 2$, aluminum dissolution $\eta_{1}$ from raw coal ash reached $81.72 \%$.

2. In the second leaching with sulfuric acid, most of the aluminum in the WLR was leached. The aluminum dissolution $\eta_{2}$ from the WLR reached $87.31 \%$ at $20{ }^{\circ} \mathrm{C}$ and $99.06 \%$ at $100{ }^{\circ} \mathrm{C}$.

3. The total aluminum dissolution $\eta$ by the twostep leaching process was more than $97 \%$, which was a significant improvement on the aluminum dissolution in the first leaching tests.

4. Amorphous silicon dioxide was the main component in the SLR, which could be a by-product of hydrated silica.

\section{Acknowledgements}

The authors acknowledge the help in the measurement of the coal ash from Mr. Jian-chun TONG (Department of Energy Engineering, Zhejiang University).

\section{References}

ASTM C618-00:2001. Annu Book ASTM Stand 04.02: Standard Specification for Coal Fly Ash and Raw or Calcined Natural Pozzolan for Use as a Mineral Admixture in Concrete. American Society for Testing and Materials, West Conshohocken.

Bai, G., Teng, W., Wang, X., et al., 2010. Processing and kinetics studies on the alumina enrichment of coal fly ash by fractionating silicon dioxide as nano particles. Fuel Processing Technology, 91(2):175-184. [doi:10.1016/j. fuproc.2009.09.010]

Berry, E.E., Hemmings, R.T., Golden, D.M., 1986. Enhanced resource recovery by beneficiation and direct acid leaching of fly ash. MRS Proceedings, London, UK. Cambridge University Press, Cambridge, UK, p.365.

Cao, D.Z., Selic, E., Herbell, J.D., 2008. Utilization of fly ash from coal-fired power plants in China. Journal of Zhejiang University-SCIENCE A, 9(5):681-687. [doi:10. 1631/jzus.A072163]

ChPC (Chinese Pharmacopoeia Commission), 2000. Pharmacopoeia of People's Republic of China, Vol. 2. Chemical Industry Press, Beijing, China (in Chinese).

Dai, S.F., Jiang, Y.F., Ward, C.R., et al., 2012. Mineralogical and geochemical compositions of the coal in the Guanbanwusu Mine, Inner Mongolia, China: further evidence for the existence of an $\mathrm{Al}$ (Ga and REE) ore deposit in the Jungar Coalfield. International Journal of Coal Geology, 98:10-40. [doi:10.1016/j.coal.2012.03.003]

Du, Z.C., Li, H.Q., Bao, W.J., et al., 2011. Reaction mechanism of desilification process of high aluminum fly ash by alkali solution. The Chinese Journal of Process Engineering, 11(3):442-447 (in Chinese).

Harada, Y., Kurata, N., Furu, G., 1993. No simultaneous determination of major constituents and impurities in high-purity mullite using pressure acid decomposition. Analytical Sciences, 9(1):99-103. [doi:10.2116/analsci.9. 99]

Huang, S., Li, F., Liu, B., et al., 1999. Study on extracting germanium and aluminium from fly-ash by acid immersion method and utilization of material. Journal of Nanchang University (Engineering \& Technology), 21:85-90 (in Chinese).

Jackson, E., 1986. Hydrometallurgical Extraction and Reclamation. Ellis Horwood Ltd., John Wiley and Sons, New York, USA.

Li, J.P., Gan, J.H., Li, X.W., 2009. Leaching of aluminum and iron from boiler slag generated from a typical Chinese Steel Plant. Journal of Hazardous Materials, 166(2-3): 1096-1101. [doi:10.1016/j.jhazmat.2008.12.025]

Liu, W.C., Yang, J.K., Xiao, B., 2009. Review on treatment and utilization of bauxite residues in China. International Journal of Mineral Processing, 93(3-4):220-231. [doi:10. 1016/j.minpro.2009.08.005]

Matjie, R.H., Bunt, J.R., van Heerden, J.H.P., 2005. Extraction of alumina from coal fly ash generated from a selected low rank bituminous South African coal. Minerals Engineering, 18(3):299-310. [doi:10.1016/j.mineng.2004. 06.013]

Nayak, N., Panda, C.R., 2010. Aluminium extraction and leaching characteristics of Talcher Thermal Power Station fly ash with sulphuric acid. Fuel, 89(1):53-58. [doi:10. 1016/j.fuel.2009.07.019] 
Quispe, D., Pérez-López, R., Silva, L.F., et al., 2012. Changes in mobility of hazardous elements during coal combustion in Santa Catarina power plant (Brazil). Fuel, 94: 495-503. [doi:10.1016/j.fuel.2011.09.034]

Seidel, A., Zimmels, Y., 1998. Mechanism and kinetics of aluminum and iron leaching from coal fly ash by sulfuric acid. Chemical Engineering Science, 53(22):3835-3852. [doi:10.1016/S0009-2509(98)00201-2]

Shao, L.Y., Chen, J.F., Shi, Y.Z., et al., 2007. Minerals in feed coal and their contribution to high alumina fly ash in the Jungar Power Plant. Journal of China Coal Society, 32(4) 411-415 (in Chinese).

Wang, R.C., Zhai, Y.C., Ning, Z.Q., 2014. Thermodynamics and kinetics of alumina extraction from fly ash using an ammonium hydrogen sulfate roasting method. International Journal of Minerals, Metallurgy, and Materials, 21(2):144-149. [doi:10.1007/s12613-014-0877-x]

Xue, Q.F., Lu, S.G., 2008. Microstructure of ferrospheres in fly ashes: SEM, EDX and ESEM analysis. Journal of Zhejiang University-SCIENCE A, 9(11):1595-1600. [doi:10.1631/jzus.A0820051]

Yang, Q.C., Ma, S.H., Zhang, R., et al., 2012. Research progress of extracting alumina from high-aluminum fly ash. Multipurpose Utilization of Mineral Resources, 3:002 (in Chinese).

\section{中文概要}

题 目: 二次酸浸法提取煤灰中的氧化铝

目 的: 煤灰淔酸浸提铝通常效率不高, 主要因为灰渣中 存在含铝晶体矿物 (如莫来石、尖晶石和长石 等)。为解决含铝晶体不易与硫酸反应的问题, 本文提出二次酸浸提铝法。

创新点: 基本实现铝硅分离, 第一步酸浸实现非晶态铝的 浸出, 残渣经焙烧和水浸后, 第二步酸浸实现剩 余铝的浸出。

方 法: 1. 一次酸浸时, 硫酸直接与煤灰渣反应浸出部分 氧化铝, 提铝残渣加碳酸钠焙烧后, 含铝晶体遭 到破坏; 2. 焙烧产物经水浸溶解出硅酸钠, 水浸 残渣做 X射线衍射分析表明其主要为铝硅非晶体 活性物质, 此时可用硫酸在温和条件下浸出剩余 的铝。

结 论: 1 . 一次酸浸提铝在 $10 \mathrm{~mol} / \mathrm{L}$ 硫酸、 $120{ }^{\circ} \mathrm{C} 、 2 \mathrm{~h}$ 和 $1: 2$ 固液比的条件下, 铝浸出率为 $81.72 \% ; 2$. 用 $5 \mathrm{~mol} / \mathrm{L}$ 硫酸二次酸浸时, $20^{\circ} \mathrm{C}$ 下铝浸出率已经 达到 $87.31 \%, 100{ }^{\circ} \mathrm{C}$ 下更是达到 $99.06 \%$; 3. 综 合两次酸浸结果, 铝的浸出总效率在 $97 \%$ 以上。

关键词: 煤灰; 氧化铝; 酸浸; 焙烧 